\title{
Calories and steps! How many days of walking/hiking in the Himalayas does ONE Christmas lunch translate to?
}

\author{
JD Pillay, ${ }^{1} \mathrm{PhD} ; \mathrm{W}$ Brown, ${ }^{2} \mathrm{PhD}$ \\ ${ }^{1}$ Department of Basic Medical Sciences, Faculty of Health Sciences, Durban \\ University of Technology, South Africa, 4001 \\ ${ }^{2}$ Centre for Research on Exercise, Physical Activity and Health, School \\ of Human Movement and Nutrition Studies, University of Queensland, \\ St Lucia, Australia
}

Corresponding author: JD Pillay (pillayjd@dut.ac.za)

Background. The festive season is a time when people are at risk of overeating and weight gain. An active break during this time can help maintain energy balance.

Objectives. To determine steps taken during a walk/hike to Everest Base Camp and back and compare estimated activityrelated energy expenditure to a typical Christmas lunch.

Methods. Five adults (39-70 years) completed an 11-day walk/hike. Pedometer-measured steps were recorded at two cadences: 'aerobic' (>100 steps/minute for 10 consecutive minutes) or 'slower' steps. Activity-related energy expenditure was estimated using generic values for walking uphill/downhill at each cadence. Energy intake of a typical Christmas lunch was estimated.

Results. Participants accumulated a total of 143770 steps, or 13070 (SD 8272) steps/day, 20\% of which were 'aerobic'. Total walk-related energy expenditure was estimated at $22816 \mathrm{kcals}$, or 1901 (SD 580) kcals/day.

Conclusion. Estimated energy intake in one Christmas lunch equates to 1.7 days of walking/hiking.

Keywords. Energy intake, physical activity, energy expenditure, pedometer

S Afr J Sports Med 2015;27(4):118-120. DOI:10.17159/2078-516X/2015/ v27i4a158

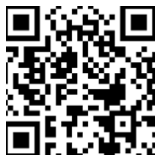

Christmas is a time when most people eat far too much food than usual, certainly more than is required to balance energy expenditure. An article in the Daily Mail ${ }^{[1]}$ advised readers to 'Think before you reach for that extra mince pie' and claimed that the food and drink consumed during Christmas lunch/dinner festivities could provide an energy intake equating with 7000 kilocalories.

One of the authors (JDP) joined four friends over Christmas in a walk/hike to Everest Base Camp (EBC) and back (starting from, and ending at, the most frequently used access to the Himalayas, Lukla International Airport). In this paper the estimated energy expenditure is compared during the 11-day hike, based on pedometer steps, and compared to energy intake based on a diet record kept by the second author who stayed at home to eat Christmas lunch.

\section{Methods}

Study design

An observational and descriptive case study.

\section{Participants and setting}

Five adults (three men, two women, aged 39-70 years) walked to EBC and back over 11 days in December 2014.

\section{Data collection}

All trek participants wore a pedometer (Omron HJ720ITC) on their hip from the start to the end of each daily walk, and daily step counts at two cadences were recorded: 'aerobic' steps were those accumulated at a cadence of $>100$ steps/minute in bouts of at least 10 minutes; 'slower' steps were accumulated at a lower cadence and/or in shorter bouts. The validity and reliability of this brand and model of pedometers have been shown to be acceptable under prescribed and self-paced walking conditions in both healthy and overweight adults. ${ }^{[2]}$ Total distances and hours of walking time were estimated from diaries and from information provided by the Himalayan National Parks Authority. ${ }^{[3]}$ Christmas lunch energy intake was estimated from the second author's food records and the tables available in the "MyFitnessPal" iPhone and Android application. ${ }^{[4]}$

\section{Data management and statistical analyses}

General characteristics of the study group and number of total steps, 'aerobic' steps and 'slower' steps each day, and estimated walk-related energy expenditure were summarised using descriptive statistics (SPSS, version 23.0). Walk-related energy expenditure was calculated by multiplying time (hours) spent in 'slower' steps by 5 METs (ascending) or 4 METs (descending), and time spent in 'aerobic' steps by 7 METs (ascending) and 6 METs (descending), hence allowing for the greater amount of energy needed to walk uphill. Resulting MET.hours values for 'aerobic' and 'slower' steps were summed, and multiplied by average body weight to derive kcals/day of energy expenditure. Summary data are reported as means and standard deviations.

\section{Results}

\section{Participant characteristics}

Participants were three men and two women, average age 54.8 (SD 11.1) years, average weight 66.1 (SD 8.4) $\mathrm{kg}$ and average body mass index 24.0 (SD 1.8) kg/m².

\section{Average daily and total steps}

Step data and estimated walk-related energy expenditure values are shown in Table 1 . The average total steps recorded during the hike to EBC and back was 143770 or an average of 13070 (SD 8272) steps/ day. The inter-individual variability, expressed as the co-efficient of variance in mean steps/day was $63 \%$ (SD/mean steps ${ }^{*} 100$ ). Approximately one-fifth of these steps were at the 'aerobic' cadence. Step counts on 'ascent days' (Days 1, 2, 4, 5, 7 and 8) ranged from 6265 to 12748 steps/day, with fewer steps on Days 3 and 6, which were 'acclimatisation' days, involving shorter hikes. Step counts on 'descent days' (Days 9, 10 and 11) were much higher, in keeping with the easier downhill walking.

\section{Estimates of energy expenditure and energy intake}

Energy expenditure in 'aerobic' steps (61.53 MET.hours in total) accounted for about one fifth of total energy expenditure. Overall, total walk-related energy expenditure was $21093 \mathrm{kcals}$, or 1918 kcals/day. 
Table 1. Daily steps, walking time and estimated energy expenditure ( $\mathrm{N}=5 ; 3$ men, 2 women, aged 39-70 years)

\begin{tabular}{|c|c|c|c|c|c|c|c|c|c|}
\hline $\begin{array}{l}\text { Day of } \\
\text { hike }\end{array}$ & $\begin{array}{l}\text { Total } \\
\text { steps/day }\end{array}$ & $\begin{array}{l}\text { 'normal' } \\
\text { steps/day }\end{array}$ & $\begin{array}{l}\text { 'aerobic' } \\
\text { steps/day }\end{array}$ & $\begin{array}{l}\text { Total } \\
\text { walk time } \\
\text { (hours/day) }\end{array}$ & $\begin{array}{l}\text { 'normal' } \\
\text { walk time } \\
\text { (hours/day) }\end{array}$ & $\begin{array}{l}\text { MET.hours } \\
\text { for 'normal' } \\
\text { walking }^{\mathrm{a}}\end{array}$ & $\begin{array}{l}\text { 'aerobic' } \\
\text { walking time } \\
\text { (hours/day) }\end{array}$ & $\begin{array}{l}\text { MET.hours } \\
\text { for 'aerobic' } \\
\text { walking b }\end{array}$ & $\begin{array}{l}\text { Energy } \\
\text { Expenditure } \\
\text { (kcal/day) }^{c}\end{array}$ \\
\hline Day 1 & 10713 & 9257 & 1456 & 3.75 & 3.38 & 16.88 & 0.38 & 2.63 & 1287 \\
\hline Day 2 & 10902 & 10902 & 0 & 7.00 & 7.00 & 35.00 & 0.00 & 0.00 & 2310 \\
\hline Day 3 & 4276 & 4087 & 189 & 3.00 & 3.00 & 15.00 & 0.00 & 0.00 & 990 \\
\hline Day 4 & 11023 & 10855 & 168 & 6.00 & 6.00 & 30.00 & 0.00 & 0.00 & 1980 \\
\hline Day 5 & 12748 & 10400 & 2348 & 6.00 & 4.80 & 24.00 & 1.20 & 8.40 & 2138 \\
\hline Day 6 & 1917 & 1453 & 464 & 2.50 & 2.00 & 10.00 & 0.50 & 3.50 & 891 \\
\hline Day 7 & 6265 & 6265 & 0 & 6.00 & 6.00 & 30.00 & 0.00 & 0.00 & 1980 \\
\hline Day 8 & 9230 & 8430 & 800 & 8.00 & 7.20 & 36.00 & 0.80 & 5.60 & 2746 \\
\hline Day 9 & 25746 & 15477 & 10270 & 7.00 & 4.80 & 19.20 & 3.20 & 19.20 & 2534 \\
\hline Day 10 & 23609 & 15393 & 8215 & 7.00 & 4.90 & 19.60 & 2.10 & 12.60 & 2125 \\
\hline Day 11 & 27341 & 19173 & 8167 & 8.00 & 5.60 & 22.40 & 1.60 & 9.60 & 2112 \\
\hline Total & 143770 & 111692 & 32077 & 65.25 & 54.68 & 258.08 & 9.78 & 61.53 & 21093 \\
\hline Average & 13070 & 10154 & 2916 & 5.9 & 5.0 & 23.10 & 0.90 & 5.70 & 1901 \\
\hline $\begin{array}{l}\text { Standard } \\
\text { deviation }\end{array}$ & 8272 & 4951 & 3750 & 1.91 & 1.57 & 8.12 & 1.00 & 6.02 & 580 \\
\hline
\end{tabular}

Estimated MET.hours/day for 'aerobic' and 'normal' walking are also shown in Table 1.

The energy value of food and drink consumed in a typical Christmas lunch is shown in Table 2. The overall energy intake in this single meal was 3295 kcals, which equates with about 1.7 days of walking/hiking in the Himalayas (see Table 1 and Table 2).

\section{Discussion}

During an 11-day hike to EBC, five people each accumulated about 13000 steps/day, which equates to an estimated walk-related energy expenditure of about $1900 \mathrm{kcals} /$ day. During this time one person sat at home and consumed $3295 \mathrm{kcals}$ in one Christmas lunch. Over-consumption of food and drink during the festive season is common and is not restricted to a single day, as it is not uncommon to have several Christmas meals with different friends/family groups during this period. The data presented here illustrate how one group addressed the energy imbalance of Christmas, while participating in an exciting expedition to the Himalayas. In doing this, it was estimated that one Christmas lunch was the equivalent of 1.7 days of walking/hiking at an average 13070 steps/day. Current public health messages support the accumulation of at least 10000 steps/day, and using these caloric and step/day estimates, 2.2 days of accumulating 10000 steps might be adequate to work off that Christmas lunch. These estimates were, however, based on at least one-fifth of these steps being accumulated at a moderate-fast pace.

To the authors' knowledge this is the first study to record pedometer steps during an 11-day hike with the data being translated to estimates of energy expenditure. A pedometer was used to allow the estimation of steps that accords with the notion of 'aerobic' activity in bouts of at least ten minutes, which is the level of activity recommended in many national physical activity guidelines. ${ }^{[5]}$ A limitation of the method in this study was that generic MET values were used to account for intensity. Under conditions of extreme (subzero) temperatures and altitude, even very slow movement involves significant exertion, so these MET values (ranging from 4 to 7 ) were
Table 2. Estimated energy of a Christmas lunch using MyFitnessPal App

\begin{tabular}{|c|c|c|}
\hline Item & $\begin{array}{l}\text { Approximate } \\
\text { serving size }\end{array}$ & $\begin{array}{l}\text { Approximate } \\
\text { kcals }\end{array}$ \\
\hline Sparkling champagne & $2 \times 150 \mathrm{ml}$ & 215 \\
\hline Red wine (Shiraz) & $2 \times 175 \mathrm{ml}$ & 240 \\
\hline Vegetable soup & $200 \mathrm{ml}$ & 160 \\
\hline Roast turkey & $120 \mathrm{~g}$ & 150 \\
\hline Roast pork & $100 \mathrm{~g}$ & 260 \\
\hline Crackling & $20 \mathrm{~g}$ & 130 \\
\hline Sausages & 2 & 130 \\
\hline Roast potato & $100 \mathrm{~g}$ & 160 \\
\hline Roast parsnip & $65 \mathrm{~g}$ & 125 \\
\hline Brussels sprouts & $100 \mathrm{~g}$ & 60 \\
\hline Broccoli & $100 \mathrm{~g}$ & 35 \\
\hline Green beans & $100 \mathrm{~g}$ & 31 \\
\hline Gravy & 3 tablespoon & 40 \\
\hline Bread sauce & $50 \mathrm{~g}$ & 50 \\
\hline Stuffing & $1 / 4$ cup & 75 \\
\hline Cranberry sauce & 2 tablespoon & 55 \\
\hline Christmas pudding & 1 slice & 300 \\
\hline Brandy butter & $25 \mathrm{~g}$ & 120 \\
\hline Custard & $1 / 2$ cup & 160 \\
\hline Mince pie & 1 & 109 \\
\hline Cheese - Stilton & $30 \mathrm{~g}$ & 125 \\
\hline Cheese - camembert & $30 \mathrm{~g}$ & 95 \\
\hline Biscuits & 6 small & 120 \\
\hline Baileys & $50 \mathrm{ml}$ & 165 \\
\hline Chocolate balls & 2 & 150 \\
\hline Cherries & $1 / 2$ cup & 35 \\
\hline TOTAL & & 3295 \\
\hline
\end{tabular}


chosen to reflect the authors' perceptions of the effort involved in walking up and downhill in these conditions. In comparison, three METs is indicative of walking at a moderate intensity on flat ground. ${ }^{[6]}$

\section{Conclusion}

This case study provides information on steps/day during an 11-day hike along a popular mountain range. It also highlights the potential imbalance of energy intake and expenditure over the festive season. The authors are not proposing that everyone should go to the Himalayas to walk off their Christmas lunch, but a daily walk with an energy expenditure equivalent to around $1900 \mathrm{kcals}$, as shown here for this 11-day walk, will offset $60 \%$ of the energy consumed in a typical Christmas meal.

Authorship. All authors consent to publication.

Competing interests. The authors declare that they have no competing interests. The manuscript has not been previously published and is not presently under consideration by another journal, and will not be submitted to another journal before the final editorial decision is rendered.
Contributorship. JDP was responsible for the acquisition of pedometer data and WB estimated the energy content of Christmas lunch. Both authors contributed to analysis and interpretation of the data and to the writing of the manuscript.

Acknowledgements. The authors wish to use this opportunity to pay tribute to those recently affected by the natural disasters in Nepal. They also thank the trek participants for collecting the pedometer data during their holiday.

\section{References}

1. The Daily Mail. Think before you reach for that extra mince pie! Published by Caroline McGuire for mailonline. 16 December 2014. [http://www.dailymail.co.uk/ femail/food/article-2874990/FEMAIL-lists-7-000-calories-average-Christmas-Daydinner.html]

2. Holbrook EA, Barreira TV, Kang M. Validity and reliability of Omron pedometers for prescribed and self-paced walking. Med Sci Sports Exerc 2009;41(3):670-674 [https://dx.doi.org/10.1249/MSS.0b013e3181886095]

3. Great Himalayan National Park. [http://greathimalayannationalpark.com] Accessed September 7, 2015.

4. Connected Fitness (2013). MyFitnessPal (version 6.6.1)[Mobile Application Software] [http://www.MyFitnessPal.com]

5. World Health Organisation. Global recommendations on physical activity for health. Geneva: World Health Organisation; 2010.

6. Blair SN. How to assess exercise habits and physical fitness. In: NE Miller, JD Matarazzo, SW Weiss, JA Herd, eds. Behavioral health: A handbook of health enhancement and disease prevention. New York: Wiley; 1984. 